\title{
Harmless Pregnancy-Induced Warm Autoantibodies to Red Blood Cells
}

\author{
Gülüstan Sürücü $^{\mathrm{a}} \quad$ Beate Mayer $^{\mathrm{a}} \quad$ Anneliese Märzacker $^{\mathrm{b}} \quad$ Salih Yürek $^{\mathrm{a}} \quad$ Abdulgabar Salama $^{\mathrm{a}}$ \\ a Institute for Transfusion Medicine, Charité - Universitätsmedizin Berlin, Berlin, Germany; \\ ${ }^{\mathrm{b}}$ Labor Schottdorf MVZ GmbH, Augsburg, Germany
}

\section{Keywords}

Pregnancy-induced autoantibodies · Red blood cells · Haemolysis · Anaemia

\section{Summary}

Background: There is little information concerning the development and significance of autoantibodies (aab) to red blood cells (RBCs) during pregnancy. Methods: Unselected pregnant women were routinely screened for the presence of unexpected antibodies to RBCs using standard techniques. Results: Between 2009 and 2013, 153,612 pregnant women were tested. The antibody screening test was positive in 1,721 women $(1.12 \%)$. In $1,602(1.04 \%)$ cases, immune and/or non-immune alloantibodies and cold-reactive aab were detected, whereas warm-reactive aab were found in 119 women (0.08\%). In almost all cases, warm-reactive aab belonged to the IgG class. No evidence of the presence of significant haemolysis in affected women was observed. Conclusion: Pregnant women may rarely develop aab to RBCs, which do not appear to cause haemolytic anaemia. Further clarification is required on the reasons behind the development of these aab and their clinical insignificance.

(c) 2015 S. Karger GmbH, Freiburg

Gülüstan Sürücü and Beate Meyer contributed equally to this work.

\section{Introduction}

Following the introduction of anti-D immunoprophylaxis in the late 1960s, the development of sensitive methods for detection of antibodies to red blood cells (RBCs) and advances in the diagnosis and treatment of foetal anaemia, there has been a marked decrease in the occurrence of severely affected or deceased foetuses due to alloantibody-induced foetal and/or neonatal haemolytic anaemia [1-4].

Nevertheless, maternal IgG alloantibodies to other RBC antigens remain significant, particularly anti-c and anti-K. Other reported antibodies are less harmful and may cause significant haemolysis only in isolated cases, e.g., anti-E, anti-Jk or anti-Fy [5-8].

Though pregnancy has not been considered to be associated with an increase in autoimmunisation in general [9-12], autoantibodies (aab) to RBCs were found to be significantly more frequent in pregnant women when compared to an age-matched non-pregnant cohort [13]. Furthermore, exacerbation of autoimmune haemolytic anaemia (AIHA) of the warm type may occur during pregnancy and involves the babies of affected women [14]. In one study, the occurrence of aab to RBCs in pregnancy was often insignificant or associated with mild haemolysis [15]. It remains unclear whether the aab described in the aforementioned study were present independent of pregnancy or were induced by pregnancy. We previously demonstrated that pregnancy-induced aab to RBCs are likely harmless, unlike classic aab in true AIHA [13].

In the present study, the occurrence of aab to RBCs in a large population of pregnant women is presented.

\section{Material and Methods}

Pregnant women routinely evaluated between 2009 and 2013 were included in this retrospective study. Unfortunately, there was no information regarding

\section{KARGER \\ Fax +497614520714

\section{(c) 2015 S. Karger GmbH, Freiburg}

1660-3796/15/0425-0325\$39.50/0 
Fig. 1. Serological findings in pregnant women. allo-ab $=$ Alloantibodies; cold $\mathrm{aab}=$ cold-reactive autoantibodies; warm aab $=$ warm-reactive autoantibodies.

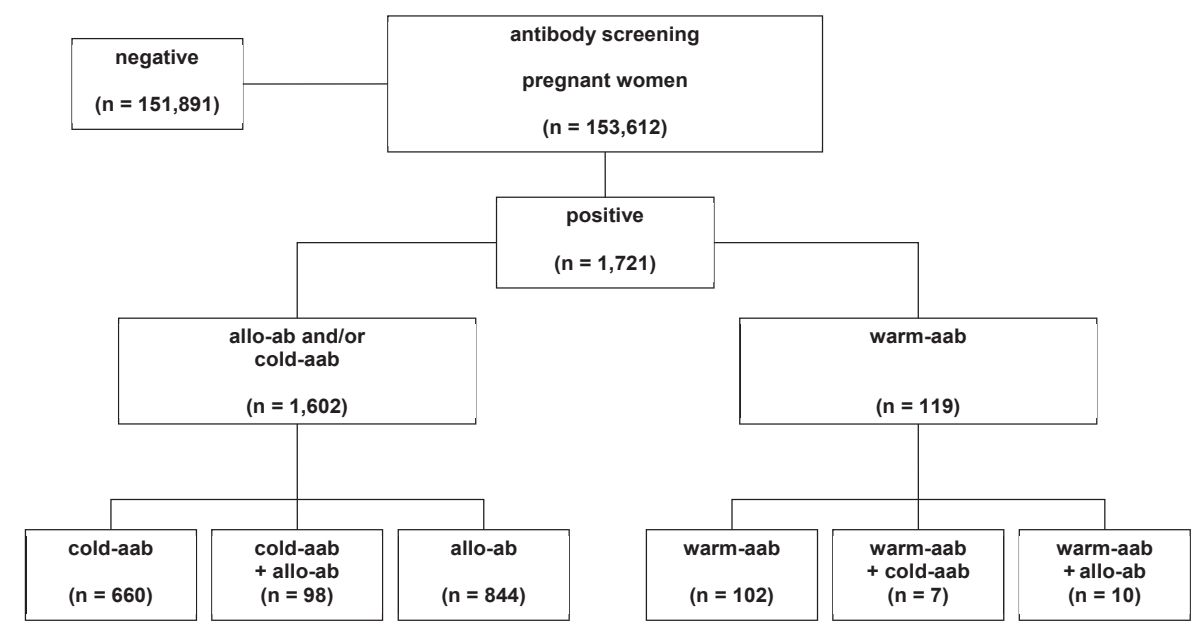

Table 1. Specificity of all alloantibodies detected in 952 pregnant women during observation

\begin{tabular}{|c|c|}
\hline Antibody & $\mathrm{n}$ \\
\hline Anti-D* & 205 \\
\hline Anti-M & 152 \\
\hline Anti-E & 143 \\
\hline Anti-P1 & 109 \\
\hline Anti-Le ${ }^{a}$ & 78 \\
\hline Anti-c & 62 \\
\hline Anti-HI & 54 \\
\hline anti- $\mathrm{C}^{\mathrm{w}}$ & 51 \\
\hline Anti-Le ${ }^{b}$ & 48 \\
\hline Anti-C & 47 \\
\hline Anti-S & 28 \\
\hline Anti-Jk ${ }^{\mathrm{a}}$ & 24 \\
\hline Anti-Wra & 24 \\
\hline Anti- $\mathrm{Lu}^{\mathrm{a}}$ & 22 \\
\hline Anti-K & 21 \\
\hline Anti-Kp ${ }^{a}$ & 12 \\
\hline Anti-Fy ${ }^{a}$ & 10 \\
\hline Anti-e & 9 \\
\hline Anti-Fy ${ }^{b}$ & 5 \\
\hline Anti-Jk ${ }^{b}$ & 5 \\
\hline Anti-N & 4 \\
\hline Anti-Lu ${ }^{b}$ & 3 \\
\hline Anti-Bg ${ }^{\mathrm{a}}$ & 2 \\
\hline Anti-Co ${ }^{b}$ & 1 \\
\hline Anti-Di ${ }^{b}$ & 1 \\
\hline Anti-f & 1 \\
\hline Anti-Jr ${ }^{\mathrm{a}}$ & 1 \\
\hline Anti-Lu8 & 1 \\
\hline Anti-s & 1 \\
\hline Anti-Yta & 1 \\
\hline Total & $1,125^{* *}$ \\
\hline
\end{tabular}

gestational age or haemoglobin concentration. The standard antibody screening test was initially performed on an automated platform (Immucor Galileo analyser, Immucor, Rödermark, Germany) using the solid-phase technology. In cases with a positive reaction, antibody identification was performed using antiglobulin gel cards and 'neutral' gel cards with untreated and enzymetreated RBCs respectively (BioRad, Cressier, Switzerland). In cases with positive autocontrols or a direct antiglobulin test (DAT), RBC-bound antibodies were eluted from the cells using an acid-elution kit (BAG, Lich, Germany), or if negative, using the heat $\left(10 \mathrm{~min}, 56^{\circ} \mathrm{C}\right)$ technique [16]. All anti-immunoglobulin reagents that were used for the monospecific DAT were obtained from commercial sources: anti-IgG, anti-IgA, anti-IgM (all three from Bio-Rad Medical Diagnostics, Dreieich, Germany), and anti-C3d (Dako, Hamburg, Germany).

The presence of warm-reactive aab to RBCs was indicated when two of the following three criteria were met: a positive DAT, detectable aab in the eluate and/or in the serum [16]. If more than one antibody screening was performed in a pregnant woman, only the strongest serological reactivity was considered in the study.

\section{Results}

During the observation period, 153,612 apparently healthy pregnant women were screened for the presence of RBC antibodies. Serum samples and/or autocontrols were positive in 1,721 $(1.12 \%)$ cases. Immune/non-immune alloantibodies and/or coldreactive aab were detected in 1,602 (1.04\%) women. In the remaining $119(0.08 \%)$ cases, warm-reactive aab alone $(\mathrm{n}=102)$ or in combination with alloantibodies $(\mathrm{n}=10)$ or cold-reactive aab $(\mathrm{n}=$ 7) were found (fig. 1, table 1). There was an IgG- and/or C3d-positive DAT in all cases. In 115 cases, the aab was eluted by acid elution, and in one case aab could only be eluted using heat technique. In another case no antibodies were eluted using both techniques, and in the remaining two women eluation was not performed due to an inappropriate sample type (table 2). Based on the laboratory requests, none of the women appeared to have developed significant haemolysis. Otherwise, treating physicians would have requested additional testing, e.g. parameters of anaemia and/or haemolysis. However, compensated haemolysis cannot invariably be excluded.

Antibody screening test was performed 2-11 times during the observation period in 88 of the 119 pregnancies. 
Table 2. Serological characterisation of samples from 119 pregnant women with warm-reactive autoantibodies

\begin{tabular}{|c|c|c|c|c|c|}
\hline \multirow[t]{2}{*}{$\mathrm{n}$} & \multicolumn{2}{|c|}{ Antibody screening } & \multicolumn{3}{|c|}{ DAT } \\
\hline & IAT & papain & IgG & C3d & eluate \\
\hline 15 & - & - & 15 & 8 & + \\
\hline 46 & - & + & 42 & 30 & + \\
\hline 53 & + & + & 47 & 36 & + \\
\hline 5 & + & - & 5 & 3 & + \\
\hline 119 & & & 109 & 77 & $116^{*}$ \\
\hline
\end{tabular}

\section{Discussion}

The results obtained in the current study support those previously reported in 2001 [13]. However, the previous study investigated only 22,782 women compared with 153,612 women in the recent study. The prevalence of pregnancy-induced aab was rather comparable in both studies (0.1 vs. $0.08 \%$ ). Based on the results of both studies, pregnancy appears to rarely stimulate the production of aab to RBCs. Nevertheless, as shown in the previous study, the occurrence of aab to RBCs in pregnant women is about five times as frequent as in a non-pregnant control group [13]. There is little information about the incidence of warm-reactive aab in healthy individuals. Our results are, however, supported by those obtained in one study where the presence of aab was also confirmed by testing of eluates. In that study the frequency of aab in healthy blood donors was found to be approximately 1:3,000 [17].

Although pregnancy-induced aab appear to be harmless for both the mother and the baby, unlike those responsible for true AIHA, the serological finding is evident in various aspects. First, the detection of abnormal IgG antibodies in pregnancy initially re- flects a risk for both the mother and child. The response of involved obstetricians varies from ignorance, due to the apparently normal condition of both the affected women and children, to a high degree of confusion and panic, resulting in unsophisticated recommendations such as repeated serological, haematological and ultrasound controls and genetic consultation. In fact, based on our experience, some affected women and parents are discouraged and shocked. To avoid false alarms and unnecessary intensive investigation procedures, all involved physicians and serologists should be informed of the occurrence of such harmless aab in pregnancy.

Second, foeto-maternal microtransfusion during pregnancy may explain how pregnancy may lead to autoimmunisation against $\mathrm{RBCs}$, but rarely or not against other organs, which is recognisable in more than $96 \%$ of cases. Alpha-methyldopa, which is used to treat gestational hypertension, is another rare cause for the production of aab against RBCs during pregnancy [18].

Blood transfusion has been shown to potentially stimulate the production of aab alone or concomitantly to alloantibodies. This is also supported by the finding that such aab are infrequently associated with alloantibodies [19]. The use of the gel card and the solidphase technique may explain why this phenomenon has not been recognised in previous studies that have dealt with screening for $\mathrm{RBC}$ antibodies in pregnant women. These techniques allow for the detection of weak antibodies, which would escape detection with the previously used tube or plate techniques. A second explanation may be related to the observed positivity of autocontrols that were previously ignored or considered as clinically insignificant.

\section{Disclosure Statement}

The authors declare no conflicts of interest.

\section{References}

1 Moise KJ Jr: Management of rhesus alloimmunization in pregnancy. Obstet Gynecol 2008;112:164-176.

2 Sandler SG, Sathiyamoorthy S: Laboratory methods for Rh immunoprophylaxis: a review. Immunohematology 2010;26:92-103.

3 de Haas M, Finning K, Massey E, Roberts DJ: Anti-D prophylaxis: past, present and future. Transfus Med 2014;24:1-7.

4 Lewin S, Bussel JB: Review of fetal and neonatal immune cytopenias. Clin Adv Hematol Oncol 2015;13: 35-43.

5 Moise KJ Jr: Fetal anemia due to non-rhesus-D red-cell alloimmunization. Semin Fetal Neonatal Med 2008; 13: 207-214.

6 Brennand J, Cameron A: Fetal anaemia: diagnosis and management. Best Pract Res Clin Obstet Gynaecol 2008;22:15-29.

7 Kumar B, Ravimohan V, Alfirevic Z: Red-cell alloimmunization. Obstet Gynaecol Reprod Med 2010;20: $47-56$.
Egbor M, Knott P, Bhide A: Red-cell and platelet alloimmunisation in pregnancy. Best Pract Res Clin Obstet Gynaecol 2012;26:119-132.

9 Marolis GB, Buckley RH, Younger JB: Serum immunogbulin concentrations during normal pregnancy. Am J Obstet Gynecol 1971;109:971-976.

10 Patton PE, Coulam CB, Bergstralh E: The prevalence of autoantibodies in pregnant and nonpregnan women. Am J Obstet Gynecol 1987;157:1345-1350.

11 Rote NS: Pregnancy-associated immunological disorders. Curr Opin Immunol 1989;1:1165-1172.

12 Giacoia GP, Azubuike K: Autoimmune diseases in pregnancy: their effect on the fetus and newborn. Obstet Gynecol Surv 1991;46:723-732.

13 Hoppe B, Stibbe W, Bielefeld A, Pruss A, Salama A: Increased RBC autoantibody production in pregnancy. Transfusion 2001;41:1559-1561.

14 Petz LD, Garratty G: Immune Hemolytic Anemias, 2nd ed. Philadelphia, Churchill Livingstone, 2004.
15 Sokol RJ, Hewitt S, Stamps BK: Erythrocyte autoantibodies, autoimmune haemolysis and pregnancy. Vox Sang 1983;43:169-176.

16 Mayer B, Yürek S, Kiesewetter H, Salama A: Mixed Type autoimmune hemolytic anemia: differential diagnosis and a critical review of reported cases. Transfusion 2008;48:2229-2234.

17 Bellia M, Georgopoulos J, Tsevrenis V, Nomikou E, Vgontza N, Kontopoulou-Griva I: The investigation of the significance of a positive direct antiglobulintest in blood donors. Immunohematology 2002;18:78-81.

18 Grigoriadis C, Tympa A, Liapis A, Hassiakos D, Bakas P: Alpha-methyldopa-induced autoimmune hemolytic anemia in the third trimester of pregnancy. Case Rep Obstet Gynecol 2013;2013:150278.

19 Ahrens N, Pruss A, Kähne A, Kiesewetter H, Salama A: Coexistence of autoantibodies and alloantibodies to red blood cells due to blood transfusion. Transfusion 2007;47:813-816. 